\title{
NARROWING THE RESEARCH-PRACTICE GAP IN PROJECT MANAGEMENT
}

\author{
REDUZINDO A LACUNA ENTRE PESQUISA E PRÁTICA EM GESTÃO DE \\ PROJETOS
}

Marcirio Silveira Chaves

Doutor

Pontifícia Universidade Católica do Rio Grande do Sul - PUCRS Porto Alegre, Rio Grande do Sul, Brazil. mschaves@gmail.com

\begin{abstract}
The Project Management (PM) area is a practice-oriented domain, but practice-based approaches remain underrepresented compared to theoretical and empirical studies. This scenario makes room for a better understanding of how to promote engagement among scholars and practitioners to study practice-relevant topics, which have a daily effect on PM stakeholders. This position paper aims to contribute recommendations concerning comprehensible forms of research engagement with practitioners that will address the research-practice gap in PM. The recommendations are grounded in the research-practice gap pointed out by Management and PM researchers. They are written as actions to foster the engagement of practitioners working with practical-oriented research designs, to draw the attention of editors and conference chairs to make practitioners part of the PM field literature, and fill the gap left by researchers neglecting contributions of practical utility. The recommendations are also associated with the research process and publication, writing theses, dissertations, papers, reports, and the PM Community. Thus, the paper has a twofold contribution: 1. Raising awareness about the emergence of research engaging practitioners and academic scholars by means of different research designs; and 2. Providing a compilation of actions for improving the engagement between practitioners and researchers.
\end{abstract}

Keywords: Research-practice gap. Project-as-practice. Practical implications. Practice research. Project management.

\begin{abstract}
Resumo
A área de Gerenciamento de Projetos (GP) é um domínio orientado à prática, mas as abordagens baseadas na prática permanecem sub-representadas em comparação com estudos teóricos e empíricos. Este cenário abre espaço para um melhor entendimento de como promover o engajamento entre acadêmicos e profissionais para estudar tópicos relevantes para a prática, que têm um efeito diário nas partes interessadas em GP. Este artigo visa contribuir com recomendações sobre formas compreensíveis de engajamento de pesquisa com profissionais que abordarão a lacuna da prática de pesquisa em GP. As recomendações estão alicerçadas na lacuna prática-pesquisa apontada por pesquisadores da Administração e de GP. Elas são escritas como ações para promover o envolvimento de profissionais que trabalham com projetos de pesquisa orientados à prática, para chamar a atenção de editores e responsáveis por conferências para tornar os profissionais parte da literatura de campo de GP e preencher a lacuna deixada por pesquisadores que negligenciam contribuições de utilidade prática. As recomendações também estão associadas ao processo de pesquisa e publicação, redação de teses, dissertações, artigos, relatórios e à comunidade de GP. Assim, o artigo tem uma dupla contribuição: 1. Conscientizar sobre o surgimento de pesquisas envolvendo profissionais e acadêmicos por meio de diferentes projetos de pesquisa; e 2. Fornecer uma compilação de ações para melhorar o engajamento entre profissionais e pesquisadores.
\end{abstract}

Palavras-chave: Lacuna pesquisa-prática. Projeto como prática. Implicações práticas. Pesquisa prática. Gerenciamento de projetos.

\section{Cite como}

American Psychological Association (APA)

Chaves, M. S. (2021, set./dez.). Narrowing the research-practice gap in project management. Revista de Gestão e Projetos (GeP), 12(3), 172-195. https://doi.org/10.5585/gep.v12i3.17227. 


\section{Introduction}

In the PM field, concern about the use of practical approaches to investigate research problems has been manifested by such lines of thought as Rethinking Project Management Network (Cicmil et al., 2006) and Project-as-practice (Blomquist et al., 2010; Hallgren \& Soderholm, 2011; Kalogeropoulos et al. 2020). However, these efforts and practice-based approaches remain under-represented in PM research (Clegg, Killen, Biesenthal, \& Sankaran, 2018), which leads to researchers continuously neglecting the practical utility of these contributions (Barrett \& Oborn, 2018). In this context, it is necessary to better understand how to promote engagement among scholars and practitioners to study practicerelevant topics that really affect PM stakeholders on a daily basis.

On the other hand, there is another stream of research conducting studies with a healthy distance to the practice. More engagement in theorizing is associated with greater impact (Colquitt \& Zapata-Phelan, 2007). To Piercy (2011, p. 1), "What is wrong with a healthy degree of antagonism between the world of ideas and the world of action?" Yip (2011) suggests that while the actual relevance of research is ultimately demonstrated when its results are usable by managers, most research does not need to yield "immediately relevant" results for managerial practice. Rowe and Markus in (Hovorka et al., 2019) mention that we will not help practitioners by attempting to replicate the tacit understanding of their work settings. Nor does the long tradition of hypothetico-deductive research in social by sciences encourage researchers to investigate the routine of organizations using practitioners as partners of the research. Such tradition focuses on basic research, with the practice itself taken for granted, thus hindering a better understanding of the complex reality of project management practice. Makin (2021) adds that many attempts to understand the causes of the researchpractice gap have failed because the answers do not reside in academia.

In this paper, I argue that there is a need for more engagement between practitioners and academic scholars in PM research. This paper intends to draw the attention of the PM community to a narrower engagement with reflective practitioners throughout the research life cycle. This approach will generate a deeper understanding of what is really occurring in projects. Close empirical attention to locally situated actions will 
enable PM researchers to generate results that are immediately applicable to projects and organizations. Taking into account that most of what management researchers do fails to resonate with management practice (Bansal et al., 2012), I contend that there is a need for a deeper understanding of the reality of project work practice in PM by using research designs that allow the delivery of effective and valuable practical results. In line with Hirschheim (2019), PM scholars should focus on questions like these — "What new insights does the research generate, in particular as they relate to changing or helping practice? Do the insights resonate with practitioners? How would these insights change the way practitioners see particular problems, particular solutions?" (p. 1343). The answers to these questions will allow PM scholars and practitioners to co-create better management practices.

Thus, this position paper can be justified by 1 . the emergence of research engaged with practice (Geraldi \& Söderlund, 2016, 2018); 2. the reduction of public funding for research in public and private universities (El Pais, 2019), which will make scholars search for private funding together with practitioners; and 3. theorizing with managers is an effective way of producing and socializing both academically sound and managerially relevant knowledge (Nenonen et al., 2017). This position paper has a twofold contribution. 1. Raising awareness about the emergence of research engaging practitioners and project management scholars by introducing research approaches to deal with real organizational problems that engage practitioners and researchers. In addition, drawing attention to journal editors and events track chairs to make more room for research that engages practitioners and academics through distinct types of papers, and 2. Providing a compilation of actions for improving the engagement between practitioners and researchers. These actions will allow researchers to face the challenges and opportunities that practice research affords PM scholarship.

This paper has the following structure: From identifying the research gap on the engagement between researchers and practitioners, the advantages of research using the practical approach are identified. This approach can be implemented through several research designs that are presented in the sequence of the article. Finally, recommendations are made to 
advance the PM field, based on the research gap, the need to use the practical approach and the research designs.

Before trying to fill the researchpractice gap, it is necessary to understand three concepts from practice theory (Whittington, 2006): Praxis, the actions of practitioners or the situated doings of an individual which include creating a sprint planning or sprint review, writing the project integration plan, and preparing a presentation for the PMO; Bredillet, Tywoniak and Dwivedula (2015) add two meanings to praxis. First, praxis as competence development and insight trying to answer 'how do we decide what is right?' (e.g., lessons learned across project experience, reflective practice vis-à-vis the context) and, second, praxis as doing: virtuous performance, and practical reasoning in the sense of 'doing the right things, getting things done' (e.g., non-technical risk management, stakeholder management). This paper uses praxis in both senses; Practice, the overall rules, guidelines, and values that direct the praxis of the practitioner which include using PM software or know how to elaborate temporary contracts; and Practitioner, the actor who conducts the praxis and practices, which includes
Scrum Masters, Project Owners, and project managers.

\section{The research-practice gap and the engaging of scholars and practitioners}

A gap is the difference between what practitioners believe and what is actually true according to empirical evidence (Rynes, 2007). A gap can be described "as dichotomous (i.e., the gap exists or it does not) or continuous in manner (i.e., the gap varies from positions of "relatively insignificant" to "highly significant")" (Ireland, 2012, p. 263).

The term research-practice gap has already been widely defined in the literature. The research-practice gap is "the failure of organizations and managers to base practices on the best available evidence" (Rousseau, 2006, p. 256). The research-practice gap is filled by adopting applied research approaches instead of basic research. According to the Organisation for Economic Cooperation and Development (OECD), basic research is carried out primarily to gain new knowledge without applied objectives. Likewise, applied research also makes it possible to acquire new knowledge, but with a specific practical purpose (OECD, 2018). Applied 
research is a form of systematic inquiry involving the practical application of science. It accesses and uses the accumulated theories, knowledge, methods and techniques of the research community for a specific business, or client-driven purpose (Roll-Hansen, 2009). This paper focuses on applied research.

The research-practice gap has been studied under other names, such as management research-management practice gap (Shapiro, Kirkman, \& Courtney, 2007), theory-praxis gap (Nenonen et al., 2017), and a knowledge transfer problem and knowledge production problem (Van de Ven, \& Johnson, 2006). Whatever the name, apart from rare exceptions in PM, academics and managers live in different worlds, so the gap is wide (Shapiro, Kirkman, \& Courtney, 2007).

To fill this gap, researchers can engage with practice using three different modes (Orlikowski, 2010): first, as an empirical phenomenon that looks at what is actually happening; second, as a theory-building perspective that is centered on practices; and third, as a philosophy that recognizes practice as both constituted by and constitutive of social and organizational realities. To better comprehend the practice, scholars should clarify how their research is engaging with the reality of an organization.

The project-as-practice approach has been used to provide new insights into what is really happening in the daily project work. "Researching the actuality of projects means focusing on social process and how practitioners reason in action in a living present" (Cicmil et al., 2006). Project-as-practice searches to comprehend what affects the day-to-day running of the projects. Project-aspractice research focuses on the stakeholders (internal and external) and their tasks. Practice is seen as a phenomenon, for which the central notion is what happens 'in practice' as opposed to what is derived or expected from 'theory' (Orlikowski, 2016). The contribution to the understanding of projects based on the everyday actions of the practitioners (Blomquist et al., 2010) can complement the process-oriented approach (development tools, methods, and models). Project-as-practice research is often based on an inductive approach (bottom-up) to be better connected to the reality of projectized organizations. Bottom-up initiatives allow the understanding of the management of problem-based organization. The unit of analysis is 
communities rather than functional units.

Examples of these communities include distributed teams and communities of practice. Inter-organizational and extraorganizational issues are also relevant questions to be explored, in an attempt to understand the day-by-day actions of practitioners. By using a project-aspractice approach, researchers facilitate the almost immediate application of the results in organizations.

\section{Research designs engaging researchers and practitioners}

One of the most relevant decisions to fill the research-practice gap is the design of the research. Regarding the research designs to underpin studies engaging reflective practitioners and academic scholars, a set of methods can be applied to conduct research near the practitioner reality. The GP community has very little explored practicaloriented paradigms such as Pragmatism and Design Science and interventionist methods such as action research and action design research.

Although practitioners do not appreciate the scientific methodological nomenclature enough, scholars should understand and apply it to maintain research rigor. Furthermore, the research designs should be rethought to meet the expectations of researchers and practitioners engaged in producing useful knowledge for all stakeholders. The challenge is how gap-bridging research should be conducted in practice. This section puts forth examples of research designs that consider the practitioner's view and work within a collaborative setting of scholars and practitioners in order to narrow the research-practice gap in PM.

First, scholars must explain the research philosophy adopted in the study they are conducting. The definition of the research philosophy (ontology and epistemology) (Sarhadi, Yousefi, \& Zamani, 2018) should be aligned with the problem stated at the beginning of the research. Rather than the positivism and interpretivism used in most basic research, applied approaches call for philosophical stances such as Design Science (Fuller, 1957; Van Aken, 2005) and Pragmatism (Peirce, 1905). While Design Science focuses on developing and evaluating artifacts, pragmatism highlights the need for a focus on actions and practices (Goldkuhl, 2004). The pragmatic avenue allows us to understand the 'realities' of the profession (Geraldi \& Söderlund, 2018). Research philosophies still need to be more and better described in 
research designs. Analyzing 40 Design Science Research (DSR) doctoral theses, Cater-Steel, Toleman \& Rajaeian (2019) found that $45 \%$ did not discuss research philosophy. By making explicit the philosophy adopted in each study, researchers will facilitate the choice of evaluation criteria used by reviewers and readers. A review and discussion on research philosophies are out of the scope of this paper. For a review of social sciences philosophies, Bechara and Van de Ven (2007) is recommended, while Susman and Evered (1978) approach the deficiencies in positivist science.

Several research methods can be used in line with the research philosophy chosen, such as DSR focusing on the development of artifacts (Hevner \& Chatterjee, 2010), Inquiry as a social learning process (Dewey, 1938), Action research (AR) (Susman \& Evered, 1978; Davison, Martinsons \& Kock, 2004) and its more than 15 nuances (Davison, Martinsons \& Malaurent, 2021), mixed methods (Leech \& Onwuegbuzie, 2009) and ethnography (Myers, 1997). All of these demand active, reflective, and empowered scholars and practitioners, including, for example, project managers, team, SCRUM Master, and PO. While using them, researchers are interested in capturing the statement of project actors about what they perceive, what they think is relevant to consider, what they do and why they do it (Lalonde et al., 2012). In addition, they are iterative, rigorous and collaborative processes. This perspective also fosters the view of project workers as active and generative creators and influencers (Narayanana \& Huemann, 2021).

DSR has been conducted under different rubrics such as action science, action research, participatory case study and academy-industry partnerships (Holmström et al. 2009). Regarding the rigor versus relevance debate (Gulati, 2007; Tushman \& O'Reilly, 2007), DSR can balance research rigor and relevance (Deng \& Ji, 2018). Research at the interface between business and academia can start by using an empirical bottomup approach based on a real organizational problem. For instance, working with DSR methodology, Peffers et al. (2007) suggest that entry points of research can be client/context initiated and problem-centered, which characterizes a bottom-up approach.

Practically-oriented methods focusing on problem-solving includes action design research (Sein et al., 2011) and the different flavors of Action Research (AR) such as canonical AR 
(Davison, Martinsons \& Kock, 2004), technical AR (Wieringa \& Moral,, 2012), and participatory AR (Chevalier \& Buckles, 2013). The challenges for action research projects include an extremely time-consuming way to collect empirical data, a high risk of projects not evolving as expected, and a close engagement with and commitment to collaborating practitioners (Simonsen, 2009). Action design research is also a highly participatory process, involving researchers, practitioners, and end-users in developing an artifact. This method highlights contributions for these stakeholders. Researchers generate design principles, practitioners receive the specific ensemble being designed and the gain for end-users is the utility of the artifact.

Although collaborative research is not limited to methods that include interventions (Pasmore et al., 2008), I advocate using interventionist approaches to shorten the time for companies to put the results generated by the research into practice. The generation of prescriptive knowledge allows managers to apply it in their companies immediately. This kind of translational research should guide PM researchers to speed up the use of knowledge generated in the academy by practitioners in the coming years.

Any research method mentioned in this section needs to collect and analyze data. Data collection techniques are the same as those used in traditional methods, such as case studies or surveys. Such techniques include interviews, focus groups, and questionnaires with PO, SCRUM Master, clients, and external stakeholders (e.g., government and society). Data analysis usually follows one of the following approaches: inductive, deductive, or abductive. Induction offers the opportunity to infer new insights and generalizations. The deductive approach involves testing a predetermined theory, explanation, or hypothesis. Abduction is when conceptual development and empirical observation are intertwined (Nenonen et al., 2017). In both data collection and analysis, researchers should take care with transparency and replicability (Aguinis \& Solarino, 2019).

To close this section, inspiring further research to be nearer to daily project work, I put forth examples of research designs engaging reflective practitioners and PM scholars, highlighting research philosophies and methods. These research designs also 
allow new ways of exploring the reality of the projects.

One approach involves the use of play ontology and ethnography and hermeneutics as a method: Salovaara et al. present a novel perspective used to describe micro activities in project settings. The metaphor of play refers to "an ontological stance that defines a phenomenon - a project - as a wave that forms in back-and-forth movements rather than an entity that can be studied as an object" (Salovaara, Savolainen, \& Ropo, 2020, p. 49).

Pragmatism and interpretivism are also paradigms that allow studies investigating the reality of the projects and the everyday actions of the practitioners. Pragmatism can be combined with shadowing and grounded-theory. By adopting the shadowing method, the researchers interact with individuals, ask questions, and gain access to in-the-moment interpretations of what is happening (Buchan \& Simpson, 2020). Pragmatism and grounded theory can aid in depicting the interactions between project actors during project conduct and gaining a deeper understanding of the processes involved, as proposed by Lalonde, Bourgault, and Findeli (2012). Interpretivism can be used with longitudinal case studies and grounded theory. For example, Eskerod and Vaagaasar (2014) set forth detailed descriptions of how a project management team worked with its stakeholder relationships in a complex development project in Scandinavia. They followed the project for two-and-ahalf years. In this same line, a research design using interpretivism with grounded theory allows theorizing with managers, producing and socializing both academically sound and managerially relevant knowledge (Nenonen et al., 2017). This design has been adopted by Kalogeropoulos et al. (2020) and Ikemoto et al. (2020).

Another way to develop collaborative research between scholars and practitioners is by using a mixedmethod approach. Rosa et al. (2016) develop a model to support the management of lessons learned in projects based on the literature and interviews with practitioners. They used a research design denominated partially mixed concurrent equal status. In this design, quantitative and qualitative elements were conducted concurrently in their entirety before being mixed at the data interpretation stage. These elements have approximately equal emphasis regarding reaching the objectives of the 
research. Cameron, Sankaran, and Scales (2015) analyze the types of mixed methods approaches used in PM.

Design science is another approach adopted by PM scholars to provide useful results for practitioners using different research designs. For instance, Scales (2020) builds a new method for schedule construction based on DSR. Narazaki et al. use design science and technical action research to develop and apply an artifact based on the interaction with project team members, project managers, and top managers in a public security organization (Narazaki, Chaves \& Pedron, 2020). Henriques and O`Neill (2021) propose a meta-model for DSR and focus groups to ensure rigorous and committed stakeholder engagement along with the research development.

Finally, the research designs proposed above can be complemented by online naturalistic inquiry (Ninan, 2020). Naturalistic data arise without a researcher intervening or providing some 'stimulus' to a group of respondents. Examples include the data collected from social media, news articles, LinkedIn profiles, WhatsApp groups, and email repositories. This kind of data is not adequately explored in project settings due to the lack of naturalistic observational data (Ninan, 2020). PM groups in social networks are rarely contacted to do more than just answer questionnaires, as seen in the very few manuscripts published by teams composed of academics and practitioners (Müller \& Söderlund, 2015).

I argue that different research designs like these bring together academic scholars and practitioners in a joint attempt to ameliorate a problematic situation and facilitate the furthering of the field of PM as an academic discipline. The research designs are also included in some recommended actions to narrow the research-practice gap.

\section{Recommended actions for the Project Management field}

Based on recent calls for improving the engagement between scholars and reflective practitioners, for example reinforcing the need for research engaged with practice (Geraldi \& Söderlund, 2016, 2018), theorizing with managers (Nenonen et al., 2017), and avoiding researchers neglect contributions' practical utility (Barrett \& Oborn, 2018), this section highlights implications for the PM field based on a list of recommended actions as follows: 
1. Involving practitioners more in the research process: Bridging the research-practice gap does not only require changes in the academic mindset but practitioners also need to change their involvement in the research process. This change can start by following the recommendations proposed by Shapiro, Kirkman, and Courtney (2007). First, to develop workshops and activities to bring scholars and practitioners together. The Academy of Management (AoM), Association for Information Systems (AIS) events, and National Association of Postgraduation and Research in Administration (ANPAD) are slowly opening their doors to receive practitioners. Second, getting practitioners involved in reviewing for conferences and journals. In addition to reviewing, I recommend practitioners help the proposition of new tracks asking for theoretical advances based on organizational problems. Third, providing hands-on help in, and outlets for, writing for practitioners. Maybe it is unnecessary to create outlets fully dedicated to practitioners at this first moment. Rather, special sections can be a more manageable initiative, such as the Research Impact and Contributions to Knowledge (RICK) special section in the
Information and Management journal (Barrett \& Oborn, 2018).

\section{Making room for genres of articles} engaging scholars and practitioners: RICK searches for papers included in five genres: Conceptual, Reviews, Translational research, Digital futures, and Global challenges (Barrett \& Oborn, 2018). This initiative is in line with Hirschheim (2019), who proposes changing how journal editors handle "applied" research. The following presents what is expected by Barrett and Oborn in each genre and how the PM community can use this classification to communicate better to the practitioners the results generated by the research. Conceptual articles should consider how to engage conceptually with translational academic research and its philosophical and methodological foundations, such as pragmatism (Barrett \& Oborn, 2018). PM researchers should develop artifacts such as frameworks and models oriented to translational research, which means being put into practice in the short term. Review articles bring together research knowledge to articulate/critique how important information systems phenomena have been addressed over time and to outline where new academic research emphasis is needed to address 
key areas of practice. Articles would offer a broad synthesis from the perspective of scholars in the field to critically unpack, review, and develop a specific research stream (Barrett \& Oborn, 2018). This genre is like traditional literature reviews with a focus on key areas of practice. PM scholars should conduct all reviews articulating the situated activities and practice of projects. Translational research articles extend the implications for practice and/or for a policy of completed scholarly research articles. These articles differ from descriptive reports of practice (practice-based research) and from conceptual articles (above) to examine how research in a specified domain has (or may in the future) influence on practice (Barrett \& Oborn, 2018). Articles in this genre possibly use interventionism approaches (e.g., action research or design science) to show the results of the engagement of scholars and practitioners in projects. Niederman et al. (2015, p.135) mention that "applying results from prior studies in new situations and testing their value when instantiated serves as a valuable link between "pure" or fundamental research and practical significance."
The remaining two genres are related to middle- and long-term research, which although not the focus of this paper, could also be considered by PM researchers. First, digital futures articles explore other approaches to project from current cumulative research knowledge to implications and potential consequences for societal and organizational futures (Barrett \& Oborn, 2018). Second, global challenges articles focus on how research can influence multidisciplinary research on the coordination among a broad set of stakeholders to address global humanitarian crises, climate change, and socioeconomic development needs (Barrett \& Oborn, 2018).

The PM community can use most of these genres to classify the manuscripts generated by their researchers. Avison, Davison, and Malaurent (2018) give recommendations for publishing engaged research.

\section{Developing new practitioner-} oriented journals: As mentioned by Shapiro, Kirkman, and Courtney (2007), if there is a knowledge transfer problem in which management research is lost in translation, then proposed solutions might focus on the development of new practitioner-oriented journals, and more 
formal recognition and rewards for publications with a substantial impact on practice. Such an impact can be demonstrated by the proposition of prescriptive models (O'Leary \& Williams, 2013; Ikemoto et al., 2020) and frameworks (Soares, Chaves \& Pedron, 2020), as well as instantiation of artifacts (Narazaki, Chaves \& Pedron, 2020). Considering that studies in projects are not only cited but also published in a variety of fields (Geraldi \& Söderlund, 2018), these new journals could also bring in their editorial calls for interdisciplinary research. It is essential to make clear that the development of practitioner-oriented journals does not imply oversimplifying research. Rather, as I argue, engagement with scholars will allow underlying rigor.

\section{Encouraging professors and} students to work in research designs that provide relevant and (not or) useful outcomes: Such outcomes can be reached by using collaborative research. By using this, scholars and practitioners will have an opportunity to put knowledge into practice. Hirschheim (2019) mentions that instead of the cycle composed by "problem $\rightarrow$ research $\rightarrow$ theory $\rightarrow$ knowledge $\rightarrow$ practice $\rightarrow$ new problems, etc., we (business academics at least) seem to operate in a cycle of problem $\rightarrow$ research $\rightarrow$ theory and then back to the problem - the knowledge and practice elements seem to have disappeared." (p. 1339). Training students and practitioners in MBA programs from the beginning can be an initiative to aid scholars to complete this cycle. Since most Information Systems doctoral students receive training in rigor but not in relevance (Moeini, Rahrovani, \& Chan, 2019), it is necessary to encourage and train our Master and Ph.D. students to conduct relevant research engaged with practitioners. In addition to a research problem framing in the papers focused on gap spotting, researchers and practitioners can also demonstrate the relevance of the examined research problems in the real world. Jarvenpaa in (Hovorka et al., 2019) adds that internship opportunities will help students communicate their research to practice audiences and redefine their research and teaching. In addition, the relevance of project management education and practitioner development has already been discussed in the literature (Crawford et al., 2006; Louw \& Rwelamila, 2012). MBA students are often practitioners with some degree of experience in projects. By applying a formal body of knowledge 
and the content of certification programs to solve real problems, these students can generate insights to feed the PM field.

\section{Strengthening theoretical and} managerial contributions by using practice theory: Using theory will allow us to strengthen theoretical and managerial contributions and the PM field as a whole. Feldman and Orlikowski (2011) present examples of how practice theory has been used in organizational literature. Floricel et al. (2014) discuss Nicolini's (2012) five dimensions of practice (work and efforts, materiality, agency and creativity, knowledge, and interests and power) and three social theories (activity theory, actor-network theory, and structuration theory.) Based on Bourdieu's practice theory within the field of PM, Kalogeropoulos, et al. (2020) suggest that project managers must be viewed from a sociological perspective as well. When researching Bourdieu's practice theory concepts of habitus, field, and capital, scholars should improve the understanding of project settings, strengthening theoretical and managerial contributions.
6. Improving the quality of managerial implications section: Most academics spend little time considering the applicability of outcomes generated by the research. To demonstrate the relevance and utility of the research findings, authors usually write this section in a normative way (i.e., recommendations for management on what to do and how to do it). Niederman et al. (2015) also note the usage of language that is opaque to practitioners. Analyzing Information Systems Strategy papers in a longitudinal study, Moeini, Rahrovani, and Chan (2019) found that the number of pages dedicated to practical implications shrank from about 1.5 pages in 2008 to 0.5 pages in 2017 . In line with Moeini, Rahrovani, and Chan (2019), reviewers and journals can seek more elaborated and standalone "Implications for practice" sections to give more details about how project stakeholders can benefit from the research results. Conversely, the Practical/Managerial Implications section in PM Ph.D. theses, Master dissertations, and papers do not often consider the various dimensions likely impacted by research. The findings can sometimes be useful to the project's internal stakeholders and the organization as a whole, crossing 
functional areas. My constructive guidance is to consider organizational implications and practical implications to the PM field when writing the Practical/Managerial Implications section in PM manuscripts. In the Organizational Implications section, make explicit the benefits generated by the research to the company (including processes, functional areas, and technology, for example) in which the intervention was carried out. In the practical implications to the PM field, provide answers to questions like these: How can the results be useful to internal and external stakeholders? How can the findings affect processes, tasks, events, and practices throughout the project life cycle? How can Product Owners, SCRUM Masters, Project Managers and team members be affected by the results generated in your research? In addition, this section can also contain a description of application scenarios with the results generated by research.

\section{Using 'action principles' to} translate understanding produced by practitioner-focused research:

Willcocks and Lacity (2016) suggest translating the understanding generated by the interaction with practitioners using 'action principles'. 'An action principle can be expressed in the following form: According to $\mathrm{n}$ participants in $\mathrm{m}$ contexts, action $\mathrm{X}$ produced result Y.' For example, according to nine interviewees in three projects from distinct organizations, using collaborative tools improved communication and social interaction among internal and external stakeholders. PM scholars can adopt this kind of representation of knowledge to help professionals practice the research project outputs. Lacity in Hovorka et al. (2019) comments on the evolution of action principles to 'Cocreate Action Principles', which means that anything the researcher writes "needs to be reviewed and approved by participants until we come to a common understanding." (p. 1370). The use of action principles should also improve the quality of the managerial implications section (recommended action \#6) by facilitating the reading of research outputs by a range of stakeholders and making explicit and direct the interventions needed in project settings.

8. Expanding the number of dissemination and communication channels: In addition, to better communicate the existing relevant cumulative research to practitioners, it is 
necessary to expand the dissemination and communication channels. Dissemination follows the regular flow to public disclosure of results using scientific language in scholarly outlets and technical reports and nonspecialized language to inform industry stakeholders and policy makers. Communication is about promoting the project and its results using nonspecialized language to communicate to the general public. Social media such as LinkedIn and Facebook, TV channels, radio, newspapers, and newsletters are used to communicate the main results of the research. In addition to posts in the personal or company profile in social networks, researchers are encouraged to write in PM and PM groups and communities registered in such social networks.

\section{Changing evaluation mechanisms:}

Public and private evaluation mechanisms should consider not only the ranking of the journal but also other factors, including how large, complex, fuzzy, and ill-structured the problems approached in the research are; whether the project crosses disciplines and stakeholder groups (engagement of relevant scientific disciplines, readiness to engage wider stakeholders - society, policy makers, and organizations beyond researchers); And, how mature are the artifacts generated by the research? In the case of $\mathrm{PM}$, results involving technological artifacts could be evaluated using Technology readiness levels (TRLs) (TRL, 2014). This method provides a common understanding of technology status and is used to make decisions concerning technology funding and technology transition. The recommendation to change evaluation mechanisms is perhaps one of those that most need to be further developed in the research evaluation, not only in PM but also in Social Science. The results achieved during the research should also be disseminated and communicated using appropriate language to reach the multiple stakeholders impacted by the research.

\section{Producing outputs, outcomes, and} impact as a result: Research results engaging scholars and practitioners can be divided into three types: Outputs are those results that are achieved immediately after an artifact is instantiated in a project or organization. They are usually used to refer to an immediate, tangible yield (e.g., a new process deployed or a new 'product' launched). Interventionist approaches 
are more recommended to generate outputs. Outcomes can be considered mid-term results, which are not seen immediately after the research. For instance, developing a project to open a new branch of an organization in another part of a country or other countries. Impact is usually a long-term result, and it may not be achievable even during the life cycle of the research (Davidson \& Barrett, 2018). The impact is also the positive and negative, primary, and secondary long-term effects produced by an intervention, directly or indirectly, intended or unintended (Picciotto, 2020). This kind of result can be measured by counting the number of views, downloads, and citations the research receives after being published, as well as its usage in organizations. Engaging practitioners and academic researchers from other fields in multidisciplinary research provides opportunities to widen research impact (Davidson \& Barrett, 2018; Jarvenpaa in Hovorka, 2019).

Recommended actions 1 and 4 aim to promote practitioners' engagement with practical-oriented research designs throughout the research life cycle. Actions 2 and 3 call for the attention of editors and conference chairs to make practitioners part of the literature of the PM field, which is currently composed almost entirely of scholars. Actions 5, 6 and 7 are proposed to fill the gap left by researchers neglecting contributions of practical utility. The ten recommended actions are also associated with the research process and publication $(1,2,3$, and 4), the writing of theses, dissertations, papers, and reports (5, 6, and 7), and the PM Community as a whole $(8,9$, and 10$)$. It is worth noting that actions 8,9 , and 10 affect all PM scholars doing applied research through outputs and theoretical research by means of outcomes.

By adopting these recommended actions, researchers and reflective practitioners will start to pave the road of knowledge in our field by narrowing the research-practice gap in PM. They must focus on understanding the reality of projects in organizations by putting the suggested actions into practice.

\section{Final remarks}

This position paper intends to raise awareness about engaging practitioners and scholars during the research process and encouraging scholars to debate the health of the PM field. Regardless of whether you agree with the argument or not, such reflection is necessary for the evolution of our 
field. It also aims to provoke a deep reflection and foster new, more imaginative discussions about practice research in the PM community. As the number of professional programs has grown in the last years in Brazil (FSP, 2018), this manuscript could inspire both newcomers in the research filed and senior scholars to become better acquainted with alternative ways to include practitioners in their research designs. I also hope that this paper can shed light on other areas in the Business and Administration field. Let us take, for example, the ANPAD divisions, looking at themes into the ADI (Information Management) division (e.g., Digital transformation, and Theoretical, Methodological and Philosophical Aspects of IS / IT Research) as well as other divisions such as EPQ - Teaching and Research in Administration and Accounting, specifically Design Science in Management and Accounting Research. It is also an initiative to show the PM field's possible connections to practice and review our research and publication practice.

Finally, I hope to start a debate, not to offer a detailed solution to this classic problem of narrowing the research-practice gap in PM. Still, I invite readers to spend some time with the 'must read' PM and PM researchers engaged in promoting scholarly research to real-world practice listed in the references of this paper. This reading will allow the PM community to have new insights into how to narrow the research-practice gap in PM. Otherwise, the theory-praxis gap will continue to widen.

\section{References}

Aguinis, H., \& Solarino, A. M. (2019). Transparency and replicability in qualitative research: The case of interviews with elite informants. Strategic Management Journal, 40(8), 1291-1315.

Avison, D. E., Davison, R. M., \& Malaurent, J. (2018). Information systems action research: Debunking myths and overcoming barriers.

Information \& Management, 55(2), 177-187.

Bansal, P., Bertels, S., Ewart, T., MacConnachie, P., \& O'Brien, J. (2012). Bridging the researchpractice gap. Academy of Management Perspectives, 26(1), 73-92.

Barrett, M., \& Oborn, E. (2018). Bridging the research-practice divide: Harnessing expertise collaboration in making a wider set of contributions. Information and Organization, 28(1), 44-51.

Bechara, J. P., \& Van de Ven, A. H. (2007). Philosophy of science underlying engaged scholarship. 
Engaged Scholarship, 12(2), 233-239.

Blomquist, T., Hällgren, M., Nilsson, A., \& Söderholm, A. (2010). Project-as-practice: In search of project management research that matters. Project Management Journal, 41(1), 5 16.

Bredillet, C., Tywoniak, S., \& Dwivedula, R. (2015). What is a good project manager? An Aristotelian perspective. International Journal of Project Management, 33(2), 254-266.

Buchan, L., \& Simpson, B. (2020). Projects-as-practice: A Deweyan perspective. Project Management Journal, 51(1), 3848.

Cameron, R., Sankaran, S., \& Scales, J. (2015). Mixed methods use in project management research. Project Management Journal, 46(2), 90-104.

Cater-Steel, A. Toleman, M. \& Rajaeian, M. M. (2019). Design Science Research in Doctoral Projects: An Analysis of Australian Theses. Journal of the Association for Information Systems, 20(12), 1844-1869.

Chevalier, J. M., \& Buckles, D. (2013). Participatory action research: Theory and methods for engaged inquiry. Routledge.

Cicmil, S., Williams, T., Thomas, J., \& Hodgson, D. (2006). Rethinking project management: researching the actuality of projects. International Journal of Project Management, 24(8), 675-686.
Clegg, S., Killen, C. P., Biesenthal, C., \& Sankaran, S. (2018). Practices, projects and portfolios: Current research trends and new directions. International Journal of Project Management, 36(5), 762-772.

Colquitt, J. A., \& Zapata-Phelan, C. P. (2007). Trends in theory building and theory testing: A five-decade study of the academy of management journal. Academy of Management Journal, 50(6), 1281-1303.

Crawford, L., Morris, P., Thomas, J., \& Winter, M. (2006). Practitioner development: From trained technicians to reflective practitioners. International Journal of Project Management, 24(8), $722-733$.

Davidson, E., \& Barrett, M. (2018). Introduction to the Research Impact and Contributions to Knowledge (RICK) Section. Information and Organization 28 (A1-A3).

Davison, R., Martinsons, M. G., \& Kock, N. (2004). Principles of canonical action research. Information Systems Journal, 14(1), 65-86.

Davison, R. M., Martinsons, M. G., \& Malaurent, J. (2021). Research Perspectives: Improving Action Research by Integrating Methods. Journal of the Association for Information Systems: 22(3), Article 1.

Deng, Q., \& Ji, S. (2018). A review of design science research in information systems: concept, 
process, outcome, and evaluation. Pacific Asia Journal of the Association for Information Systems, 10(1).

Dewey, J. (1938). Logic: The theory of inquiry. Henry Holt and Co.

El Pais (2019). Cortes de verbas desmontam ciência brasileira e restringem pesquisa a mais ricos. Available at https://brasil.elpais.com/brasil/2 019/09/03/politica/1567542296_ 718545.html. Last access: May, 15 th 2020.

Eskerod, P., \& Vaagaasar, A. L. (2014). Stakeholder management strategies and practices during a project course. Project Management Journal, 45(5), 7185.

Feldman, M. S., \& Orlikowski, W. J. (2011). Theorizing practice and practicing theory. Organization Science, 22(5), 1240-1253.

Floricel, S., Bonneau, C., Aubry, M., \& Sergi, V. (2014). Extending project management research: Insights from social theories. International Journal of Project Management, 32(7), 1091-1107.

FSP (2018). Oferta de mestrados profissionais triplica em dez anos no país. Available at https://www1.folha.uol.com.br/s obretudo/carreiras/2018/10/1983 632-oferta-de-mestradosprofissionais-triplica-em-dezanos-no-pais.shtml. Last access: May 4, 2020.

Fuller, R. Buckminster (1957). A Comprehensive Anticipatory Design Science. Royal Architectural Institute of
Canada. 34. Retrieved 2020-0509 - via Google Books.

Geraldi, J., \& Söderlund, J. (2016). Project studies and engaged scholarship. International Journal of Managing Projects in Business, 9(4), 767-797.

Geraldi, J., \& Söderlund, J. (2018). Project studies: What it is, where it is going. International Journal of Project Management, 36(1), 55-70.

Goldkuhl, G. (2004). Meanings of pragmatism: Ways to conduct information systems research. Action in Language, Organisations and Information Systems.

Gulati, R. (2007). Tent poles, tribalism, and boundary spanning: The rigor-relevance debate in management research. Academy of Management Journal, 50(4), 775-782.

Hallgren, M., \& Soderholm, A. (2011). Projects- as- practice: New approach, new insights. In P. W. G. Morris, J. Pinto, \& J.

Soderlund (Eds.), The Oxford handbook of project management. Oxford University Press.

Henriques, T.A. \& O’Neill, H. (2021). Design science research with focus groups - a pragmatic meta-model. International Journal of Managing Projects in Business. https://doi.org/10.1108/IJMPB01-2020-0015

Hevner, A., \& Chatterjee, S. (2010). Design science research in information systems. In Design 
research in information systems (pp. 9-22). Springer, Boston, MA.

Hirschheim, R. (2019). Against theory: With apologies to Feyerabend. Journal of the Association for Information Systems, 20(9), 8.

Holmström, J., Ketokivi, M., \& Hameri, A. P. (2009). Bridging practice and theory: a design science approach. Decision Sciences, 40(1), 65-87.

Hovorka, D. S., Rowe, F., Markus, L., Jarvenpaa, S., Swanson, E. B., Lacity, M. \& Hirschheim, R. (2019). Scholarly Commentaries on Hirschheim's “Against Theory". Journal of the Association for Information Systems, 20(9), 12.

Ikemoto, M.; Gantman, S.; Chaves, M. S. \& Russo, R. (2020). SOME4PM: A Prescriptive Model for Guiding Integrated Use of Social Media in Project Management. International Journal of Management and Enterprise Development, 19(4), 330-364.

Ireland, R. D. (2012). Management Research and Managerial Practice: A complex and controversial relationship. Academy of Management Learning \& Education. 11(2), 263-271.

Kalogeropoulos, T., Leopoulos, V., Kirytopoulos, K., \& Ventoura, Z. (2020). Project-as-Practice: Applying Bourdieu's Theory of Practice on Project Managers. Project Management Journal, 8756972820913392.
Lalonde, P. L., Bourgault, M., \& Findeli, A. (2012). An empirical investigation of the project situation: PM practice as an inquiry process. International Journal of Project Management, $30(4), 418-431$.

Leech, N. L., \& Onwuegbuzie, A. J. (2009). A typology of mixed methods research designs. Quality \& quantity, 43(2), 265275.

Louw, T., \& Rwelamila, P. D. (2012). Project management training curricula at South African public universities: Is the balanced demand of the profession sufficiently accommodated?. Project Management Journal, 43(4), 70-80.

Makin, S. (2021). The research-practice gap as a pragmatic knowledge boundary. Information and Organization, 100334.

Moeini, M., Rahrovani, Y., \& Chan, Y. E. (2019). A review of the practical relevance of IS strategy scholarly research. The Journal of Strategic Information Systems, 28(2), 196-217.

Müller, R., \& Söderlund, J. (2015). Innovative approaches in project management research. International Journal of Project Management, 2(33), 251-253.

Myers, M. D. (1997). Critical ethnography in information systems. In Information systems and qualitative research (pp. 276-300). Springer, Boston, MA. 
Narayanan, V. K., \& Huemann, M. (2021). Engaging the organizational field: The case of project practices in a construction firm to contribute to an emerging economy.

International Journal of Project Management.

Narazaki, R.; Chaves, M. S. \& Pedron, C. (2020). A project knowledge management framework grounded in design science research. Knowledge and Process Management, 27(3), 197-210.

Nenonen, S., Brodie, R. J., Storbacka, K., \& Peters, L. D. (2017). Theorizing with managers: how to achieve both academic rigor and practical relevance? European Journal of Marketing. 51 (7/8), pp. 1130-1152.

Nicolini, D. (2012). Practice theory, work, and organization: An introduction. OUP Oxford.

Niederman, F., Crowston, K., Koch, H., Krcmar, H., Powell, P., \& Swanson, E. B. (2015).

Assessing IS research impact.

Communications of the

Association for Information

Systems, 36(1), 7.

Ninan, J. (2020). Online naturalistic inquiry in project management research: Directions for research. Project Leadership and Society, 1,100002 .

OCDE. Glossary of Statistical Terms.

Available at:

<https://stats.oecd.org/glossary/d etail.asp?ID $=3111>$. Last access: May, 6th 2020.
O’Leary, T., \& Williams, T. (2013).

Managing the social trajectory: a practice perspective on project management. IEEE Transactions on Engineering Management, 60(3), 566-580.

Orlikowski, W. (2010). Practice in research: phenomenon, perspective and philosophy. In D. Golsorkhi, L. Rouleau, D. Seidl, \& E. Vaara (Eds.), The Cambridge handbook of strategy as practice (pp. 23-33). Cambridge University Press.

Orlikowski, W. J. (2016). Practice in research: phenomenon, perspective and philosophy. Cambridge handbook of strategy as practice, 2nd edition, 692 pages.

Pasmore, W. A., Stymne, B. E. N. G. T., Shani, A. B., Mohrman, S. A., \& Adler, N. (2008). The promise of collaborative management research. Handbook of collaborative management research, 7-31.

Picciotto, R. (2020). Towards a 'New Project Management'movement? An international development perspective. International Journal of Project Management, $38(8), 474-485$.

Piercy, N. (2011). The role of academics should be to challenge status quo. Financial Times Online. Available at: https://www.ft.com/content/ffae 61a4-0946-11e1-8e8600144feabdc0. Last access: May, 15th 2020. 
Nenonen, S., Brodie, R. J., Storbacka, K., \& Peters, L. D. (2017).

Theorizing with managers: how to achieve both academic rigor and practical relevance?

European Journal of Marketing, 51(7/8), 1130-1152.

Peffers, K., Tuunanen, T., Rothenberger, M. A., \& Chatterjee, S. (2007). A design science research methodology for information systems research. Journal of Management Information systems, 24(3), 45-77.

Peirce, C. S. (1905). What pragmatism is. The monist, 15(2), 161-181.

Sarhadi, M., Yousefi, S., \& Zamani, A. (2018). Participative project management as a comprehensive response to postmodernism criticisms: The role of communication. International Journal of Managing Projects in Business, 11(4), 935-959.

Scales, J. (2020). A design science research approach to closing the gap between the research and practice of project scheduling. Systems Research and Behavioral Science, 37(5), 804812.

Roll-Hansen, N. (2009). Why the distinction between basic (theoretical) and applied (practical) research is important in the politics of science. The London School of Economics and Political Science. Technical Report.

Rosa, D. V., Chaves, M. S., Oliveira, M., \& Pedron, C. (2016). Target: A Collaborative Model based on
Social Media to Support the Management of Lessons Learned in Projects. International Journal of Managing Projects in Business, 9(3), 654-681.

Rousseau, D. (2006). Is there such a thing as "Evidence-Based Management"?. Academy of Management Review. 31(2), 256-269.

Rynes, S. L. (2007). Editor's Afterword. Let's create a Tipping Point: What Academics and Practitioners can do, alone and together. Academy of Management Journal. 50(5), 1046-1054.

Salovaara, P., Savolainen, J., \& Ropo, A. (2020). Project Is as Project Does: Emerging Microactivities and Play Ontology. Project Management Journal, 8756972819894101.

Sein, M., Henfridsson, O., Purao, S., Rossi, M., \& Lindgren, R. (2011). Action design research. Management Information Systems Quarterly, 35(1), 37-56.

Shapiro, D. L., Kirkman, B. L., \& Courtney, H. G. (2007). Perceived causes and solutions of the translation problem in management research. Academy of Management Journal, 50(2), 249-266.

Simonsen, J. (2009). A Concern for Engaged Scholarship: The challenges for action research projects. Scandinavian Journal of Information Systems, 21(2), 1. 
Soares, R., Chaves, M. S. \& Pedron, C. (2020). W4RM - A Prescriptive Framework based on a Wiki to Support Collaborative Risk Management in Information Technology Projects. International Journal of Information Systems and Project Management, 8(1), 67-83.

Susman, G. I., \& Evered, R. D. (1978). An assessment of the scientific merits of action research. Administrative science quarterly, 582-603.

TRL (2014). Technology readiness levels (TRL). Part 19 Commission Decision C(2014)4995". ec.europa.eu. 2014. Retrieved on March 24th, 2020.

Tushman, M., \& O'Reilly III, C. (2007). Research and relevance: Implications of Pasteur's quadrant for doctoral programs and faculty development. Academy of Management Journal, 50(4), 769-774.

Van Aken, J. E. (2005). Management research as a design science: Articulating the research products of mode 2 knowledge production in management. British Journal of Management, 16(1), 19-36.

Van de Ven, A. H., \& Johnson, P. E. (2006). Knowledge for theory and practice. Academy of Management Review, 31(4), 802-821.

Wieringa, R., \& Moralı, A. (2012, May). Technical action research as a validation method in information systems design science. In International
Conference on Design Science Research in Information Systems (pp. 220-238). Springer, Berlin, Heidelberg.

Willcocks, L. \& Lacity, M. (2016). Service Automation: Robots and the future of work. London: Brookes.

Whittington, R. (2006). Completing the practice turn in strategy research. Organization Studies, 27(5), 613-634.

Yip, G. 2011. Business research needs to be more relevant for managers. Financial Times Online. Available at: https://www.ft.com/content/f42b 4028-35fb-11e0-b67c00144feabdc0 . Last access: May 18th, 2020. 